\title{
Cooking Pattern and Quality Properties of Ground Pork Patties as Affected by Microwave Power Levels
}

\author{
Jong Youn Jeong ${ }^{1}$, Eui Soo Lee ${ }^{2}$, Ji Hun Choi ${ }^{3}$, Yun Sang Choi ${ }^{3}$, Long Hao Yü, \\ Si Kyung Lee ${ }^{5}$, Chi Ho Lee ${ }^{3}$, and Cheon Jei Kim ${ }^{3, *}$ \\ ${ }^{I}$ Department of Animal Science, University of Wisconsin-Madison, Meat Science and Muscle Biology Laboratory, 1805 \\ Linden Drive, Madison WI 53706, United States \\ ${ }^{2}$ National Institute of Animal Science, RDA, Suwon 441-706, Korea \\ ${ }^{3}$ Department of Food Science and Biotechnology of Animal Resources, Konkuk University, Seoul 143-701, Korea \\ ${ }^{4}$ College of Food Science, H. L. J. August First Land Reclamation University, China \\ ${ }^{5}$ Department of Applied Biology and Chemistry, Konkuk University, Seoul, 143-701, Korea

\section{전자레인지 출력에 따른 분쇄 돈육 패티의 가열패턴 및 품질특성} \\ 정종연 ${ }^{1} \cdot$ 이의수 ${ }^{2} \cdot$ 최지훈 $^{3} \cdot$ 최윤상 $^{3} \cdot$ Long-Hao $\mathrm{Yu}^{4} \cdot$ 이시경 $^{5} \cdot$ 이치호 $^{3} \cdot$ 김천제 $^{3, *}$ \\ ${ }^{1}$ Department of Animal Science, University of Wisconsin-Madison, Meat Science and Muscle Biology Laboratory, \\ 1805 Linden Drive, Madison WI 53706, United States \\ 2농촌진흥청 국립축산과학원 \\ 3건국대학교 축산식품생물공학전공 \\ ${ }^{4}$ College of Food Science, H. L. J. August First Land Reclamation University, China \\ 5건국대학교 응용생물과학전공
}

\begin{abstract}
This study was carried out to evaluate the effects of microwave power level on cooking properties of ground pork patties (fat level: $20 \%$ ). Each patty was cooked from a thawed state to $76.7^{\circ} \mathrm{C}$ (center temperature) in a microwave oven with power levels of $40 \%(360 \mathrm{~W}), 60 \%(540 \mathrm{~W}), 80 \%(720 \mathrm{~W})$, and $100 \%$ (full power, $900 \mathrm{~W})$, respectively. Cooking rate increased with power level, and the non-uniformity also increased with time during cooking. Overheating at the edge of the patties was observed for all power levels, and maximum temperature differences in between the edge position and center position were found in patties cooked at the $900 \mathrm{~W}$ power level. Compositional properties, total cooking loss, and drip loss were not affected by power level, although moisture content was lower at the edge than at the center position. As the power level increased, the reduction in patty diameter of cooked patties increased while the reduction in patty thickness decreased. Pork patties cooked at lower power levels $(360 \mathrm{~W}$ and $540 \mathrm{~W})$ had higher shear force values than those cooked at higher power levels $(720 \mathrm{~W}$ and $900 \mathrm{~W})$. Few changes were observed in instrumental color values.
\end{abstract}

Key words : pork patties, microwave power level, microwave cooking, quality properties

\section{Introduction}

Microwaves used in the food industry are of the industrial, scientific, and medical (ISM) frequencies 2450 MHz or $900 \mathrm{MHz}$, corresponding to wavelengths of 12 or

*Corresponding author : Cheon Jei Kim, Department of Food Science and Biotechnology of Animal Resources, Konkuk University, Seoul 143-701, Korea. Tel: 82-2-450-3684, Fax: 82-2-444-6695, E-mail: kimcj@konkuk.ac.kr
$34 \mathrm{~cm}$, respectively. In this frequency range, the dielectric heating mechanism dominates up to moderated temperatures (Ohlsson, 1999). When microwaves generated by a magnetron encounter a food, the energy of the microwave may be reflected, transmitted, or absorbed. All three of possibilities are related to the dielectric properties of the product. While the energy previously absorbed is dissipated to the surroundings, that is, directly inside the food (Engelder and Buffler, 1991; Ohlsson, 1999).

In microwave cooking of foods, power levels affect 
depends not only on cooking rate, but also cooking pattern and properties. It thus is considered to reduce the quality loss. Increasing the power output usually increases the speed of microwave cooking, which is the most attractive feature of microwave cooking. However, excessive speed may adversely affect the cooked product and result in nonuniform temperature distribution. This occurs because the cooking may be so fast as to prevent the effectiveness of thermal conductivity in transferring heat to the cooler areas (Schiffman, 1986). Thus, microwaves can produce uneven heating, which is one of the major problems in microwave processing of food products. Since microwaves penetrate from all sides, the geometrical shape of the food product may have a considerable influence on its pattern of heating. Center-heating effects for spherical or cylindrical shapes result from a concentration of energy to the center of the food. This effect depends not only on the processing frequency but also on the diameter and conductivity of the product (Mudgett, 1986; Ohlsson and Bengtsson, 2001). Another undesirable heating pattern dependent upon the geometric shape of the food involves overheating at the corner and edges. In a slab with sharp corners and edges protruding into the microwave fields, energy concentrations will occur causing selective heating, especially at the corners. A sharp edge or corner will act as an antenna and attract more energy than the surrounding areas (Ohlsson and Bengtsson, 2001; Ohlsson and Risman, 1978). These effects are well documented in many literatures (Chamchong and Datta, 1999; Ni et al., 1999; Ohlsson et al., 1974; Zeng and Faghri, 1994). Zeng and Faghri (1994) studied thawing patterns for cylindrically-shaped tylose samples with different aspect ratios. Chamchong and Datta (1999) also studied mathematical and experimental data to investigate the effect of power levels and power cycling levels on thawing time and nonuniformity of tylose samples with $2-4 \%$ salt.

The majority of the above studies were performed using homogeneous food materials. However, meat patties are multi-component foods that generally consist of water, protein, and fat. Thus, the cooking pattern and properties of meat patties may be differ substantially from previously studied foods with a homogeneous composition. According to Decareau (1985), multi-component foods present a problem for microwave cooking, particularly when the components have widely different cooking properties. However, very limited researches (Nykvist and Decareau, 1976; Zhang et al., 2004) have investigated the relationship between microwave power levels and the qualities of meat products. Therefore, the purpose of this study was to evaluate the cooking pattern and the quality properties of cooked ground pork patties at different power levels.

\section{Materials and Methods}

\section{Processing and preparation}

Six fresh pork hams, weighing 6.8-7.2 kg each, were purchased from a local processor at $48 \mathrm{hr}$ postmortem. Pork backfat was also collected. All subcutaneous and intermuscular fat and visible connective tissue were removed from the fresh ham muscles. Lean materials were initially ground through a $13 \mathrm{~mm}$ plate and fat percentage was determined on raw materials before blending. The pork fat was ground through a $8 \mathrm{~mm}$ plate and added to the lean meat to create fat level of $20 \%$. The mixtures were mixed by hand for $3 \mathrm{~min}$ and grind twice using 3 $\mathrm{mm}$ plate. The ground mixtures were hand-mixed and then formed into patties (90 g each) using sterile $15 \times 90$ $\mathrm{mm}$ Petri dishes. Patties were then randomly vacuumpackaged with Nylon/PE film, frozen, and stored at $-20^{\circ} \mathrm{C}$ until testing. Pork patties processing was run in triplicate.

\section{Microwave cooking and temperature measurement}

Patties were cooked in a household-type microwave oven (Model MW5480W, Samsung Electronics Co., Ltd., Suwon, Korea) operating at $2450 \mathrm{MHz}$ with power levels of $40 \%(360 \mathrm{~W}), 60 \%(540 \mathrm{~W}), 80 \%(720 \mathrm{~W})$, or $100 \%$ (full power, $900 \mathrm{~W}$ ), respectively. Patties were maintained at $5 \pm 1^{\circ} \mathrm{C}$ for 24 to $36 \mathrm{hr}$ before cooking. Each patty was placed in the center of the oven on a microwave-safe plastic container (uncovered) with a plastic rack (approximately $8 \mathrm{~mm}$ from the bottom of the container), which allowed drips to escape from the underside, until the internal center of the patty reached the designated testing temperature $\left(76.7^{\circ} \mathrm{C}\right)$. The container was rotated inside the microwave chamber during the cooking period. Preliminary trials were conducted to determine the cooking time required to reach the designated internal temperature. The temperatures of the ground pork patties were measured from two temperature sensing locations (at the center and edge position of the mid-depth) using a fiber optic system (Optical Slip Ring System, Fiso Technologies, Quebec, Canada) and a connecting fiber optic temperature sensor (FOT-L, Fiso Technologies, Quebec, Canada) (Fig. 1). The cooling period was followed by holding in an oven for $2 \mathrm{~min}$. The above set-up was interfaced to a computer via a fiber optic system for temperature data acquisition. Immediately after microwave cooking and holding, the 


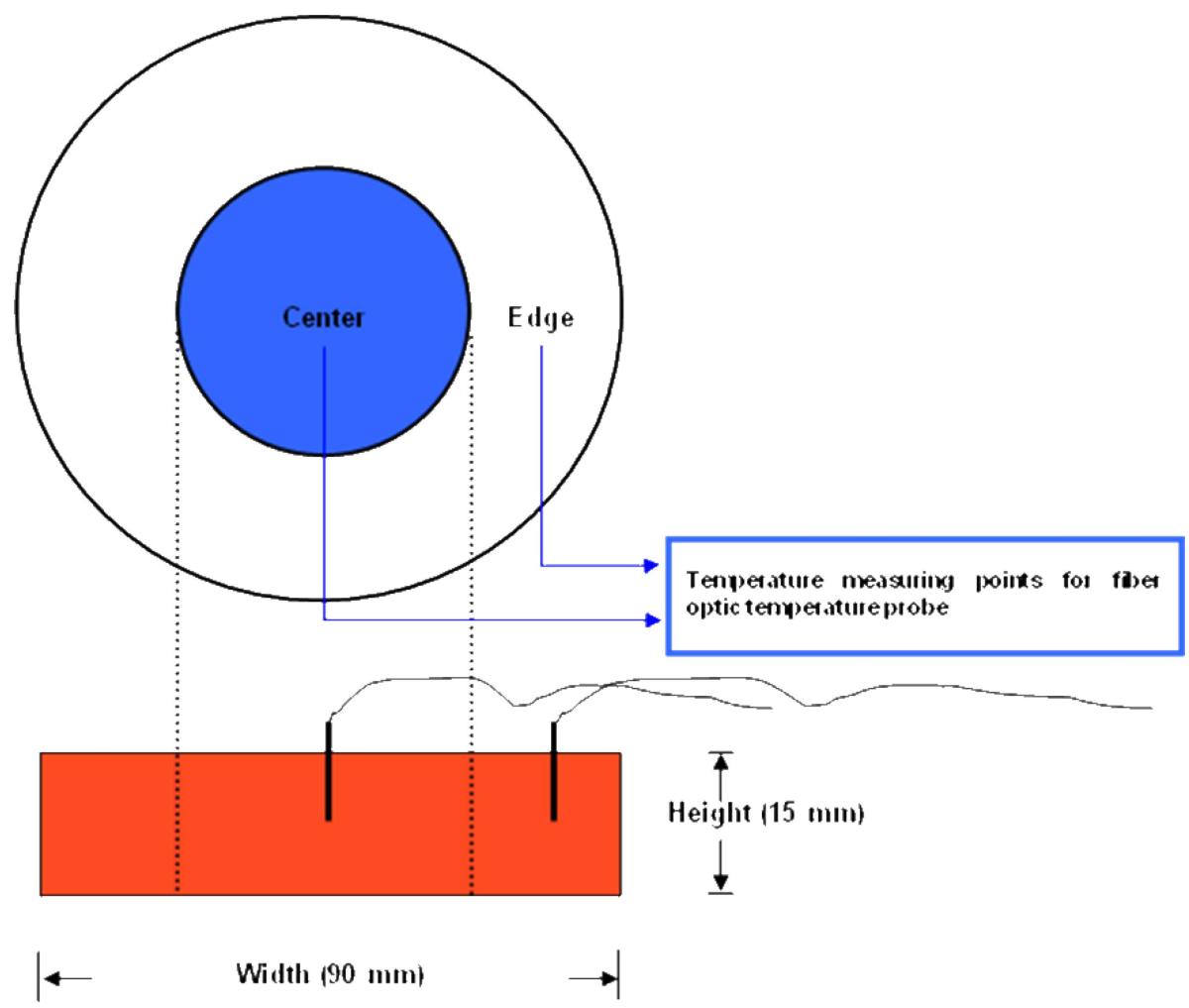

Fig. 1. Schematic diagram of sensor locations and areas in the patty. Center area: the radial distances of 2-cm from center position, Edge area: the radial distances between $2-\mathrm{cm}$ and $4.5-\mathrm{cm}$ from center position.

samples were removed from the oven, and the fiber optic temperature sensor was disconnected. And then the container including the patty and the patty alone were immediately weighed to determine cooking loss.

\section{pH measurements and compositional properties}

$\mathrm{pH}$ measurements and compositional properties were performed on six raw and cooked patties for each power level. Cooked samples were removed from the center and edge positions immediately after cooking. The $\mathrm{pH}$ value was determined with a $\mathrm{pH}$ meter (Model 340, MettlerToledo GmbH Analytical, Schwerzenbach, Switzerland) by blending a $5 \mathrm{~g}$ sample with $20 \mathrm{~mL}$ distilled water for $60 \mathrm{sec}$ in a homogenizer (Ultra-Turrax T25, Janke and Kunkel, Staufen, Germany). Moisture content was determined by weight loss after $12 \mathrm{hr}$ of drying at $105^{\circ} \mathrm{C}$ in dry oven. Fat content was determined with a solvent extraction system (Soxtec ${ }^{\circledR}$ Avanti 2050 Auto System, Foss Tecator AB, Höganas, Sweden). Protein content was determined with an automatic Kjeldahl nitrogen analyzer (Kjeltec ${ }^{\circledR} 2300$ Analyzer Unit, Foss Tecator AB, Höganas, Sweden).

\section{Cooking properties measurements}

Cooking rate, total cooking loss, drip loss, and evapora- tion loss were determined on thirty patties for each power level as follows:

Cooking rate $\left({ }^{\circ} \mathrm{C} / \mathrm{min}\right)=$

Final internal temperature-Initial internal temperature

$$
\text { Cooking time }
$$

Total cooking loss $(\%)=\frac{\text { Raw weight }- \text { Cooked weight }}{\text { Raw weight }} \times 100$

Drip loss $(\%)=\frac{\text { Drip weight }}{\text { Raw weight }} \times 100$

Evaporation loss $(\%)=$

Total cooking loss (\%) - Drip loss (\%)

The thickness and the diameter of raw and cooked patties were recorded by using Vernier calipers (530 analog types, Mitutoyo, Japan). Two identified locations were measured on each patty, one on each the half, were used to determine raw and cooked patty thickness. Percent reduction in patty thickness was determined using the following equation:

$$
\begin{aligned}
& \text { Reduction in patty thickness }(\%)= \\
& \frac{\text { Raw patty thickness }- \text { Cooked patty thickness }}{\text { Raw patty thickness }} \times 100
\end{aligned}
$$


Two measurements per patty were taken to obtain raw and cooked patty diameter, using marked locations $90^{\circ}$ from each other. Percent reduction in patty diameter was determined using the following equation:

$$
\begin{aligned}
& \text { Reduction in patty diameter }(\%)= \\
& \frac{\text { Raw patty diameter }- \text { Cooked patty diameter }}{\text { Raw patty diameter }} \times 100
\end{aligned}
$$

\section{Shear force measurements}

Ten patties per power level were cooked according to the procedures previously described and then equilibrated to room temperature for $1 \mathrm{hr}$ before sampling. Each patty was cut with a knife into $2.5 \mathrm{~cm}$ wide sections and the sections were sheared in two separate locations with a Warner-Bratzler blade set attached to a Texture Analyzer (TA-XT2 $i$, Stable Micro System Ltd., Surrey, UK). Test speeds were set at $120 \mathrm{~mm} / \mathrm{min}$. Data were collected and analyzed from the shear force values to obtain for the maximum force required to shear through each sample and expressed as shear force $(\mathrm{kg})$.

\section{Instrumental color evaluations}

Six patties per power level were used for color measurements. Immediately following cooking and weighing, cooked patties (about $13 \mathrm{~mm}$, thickness) were sliced parallel to the flat surface in the center of the samples. Instrumental color values (CIE L, a, and b values) were measured on the outer surface and on a cut surface after cooking, using a color meter (Chroma meter CR-210, Minolta Camera Co. Ltd., Osaka, Japan). The type of illuminate was $\mathrm{C}$ and the initial color was calibrated with white plate, $\mathrm{L}=+97.83, \mathrm{a}=0.43, \mathrm{~b}=+1.98$.

\section{Statistical analyses}

The experiment was replicated three times. Analyses of variance were performed on all the variables measured using the General Linear Model (GLM) procedure of the SAS statistical package (SAS, 1999). The Duncan's multiple range test $(p<0.05)$ was used to determine differences between treatment means.

\section{Results and Discussion}

\section{Time-temperature profiles during microwave cook- ing and holding period}

The temperatures were measured from the two locations at the center and edge of the ground pork patties. Typical time-temperature data are shown in Fig. 2. As expected, microwave power levels affected heating rates. Patties cooked at $900 \mathrm{~W}$ had the shortest cooking time, while patties cooked at $360 \mathrm{~W}$ had the longest. This result was consistent with the trend observed by Chamchong and Datta (1999). The rate of increase in temperature was not proportional to the increase of power. The temperature at the edge position reached approximately $90^{\circ} \mathrm{C}$ and maintained that temperature in all samples, regardless of power level. This phenomenon may be due to the evaporating effect of sample surface (Mudgett, 1988). The boiling temperature of water is $100^{\circ} \mathrm{C}$; thus, when this temperature is reached, all additional absorbed microwave energy is expected to contribute to the evaporation of water. Therefore, the temperature is maintained near $100^{\circ} \mathrm{C}$ (Chamchong and Datta, 1999; Ni et al., 1999). Differences in mean temperature between the edge position and the center position and their standard deviation resulted in non-uniformity in microwave cooking (Fig. 3). This result has been previously reported and is known as the edge effect (Buffler and Stanford, 1991; Nykvist and Decareau, 1976; Risman, 1992), which means that edge or corner area is rapidly cooked while the center part of the food remains relatively cool. This is especially prevalent in slab-shaped foods. The non-uniformity increased with time during cooking. When the edge position of the patty reached to near $100^{\circ} \mathrm{C}$, its non-uniformity had the highest, and then gradually decreased with increasing cooking time, regardless of microwave power level. According to Ni et al. (1999), since everywhere in the food tends to reach approximately the boiling temperature of water, temperature non-uniformity eventually starts to decrease. As expected, maximum temperature differences and standard deviation of differences in temperature between at the edge position and at the center position were observed in patties cooked at 900 W. Conversely, non-uniformity of temperature was lower at reduced power levels and was the lowest in patties cooked at 360 W. These results are due to the increased diffusion energy transfer, resulting in more uniformity of temperature. Thus, the effect of microwave heating is a compromise between the rate of heating and its uniformity (Zhang and Datta, 2000). Furthermore, considerable variability in mean temperature differences between at the edge position and at the center position could adversely affect the product quality by causing burning and drying of the surface near edges. These characteristics could also adversely affect the safety of the product (Fakhouri and Ramaswamy, 1993; Liu and Berry, 1996).

Post-cooking temperature rise at the center and edge 

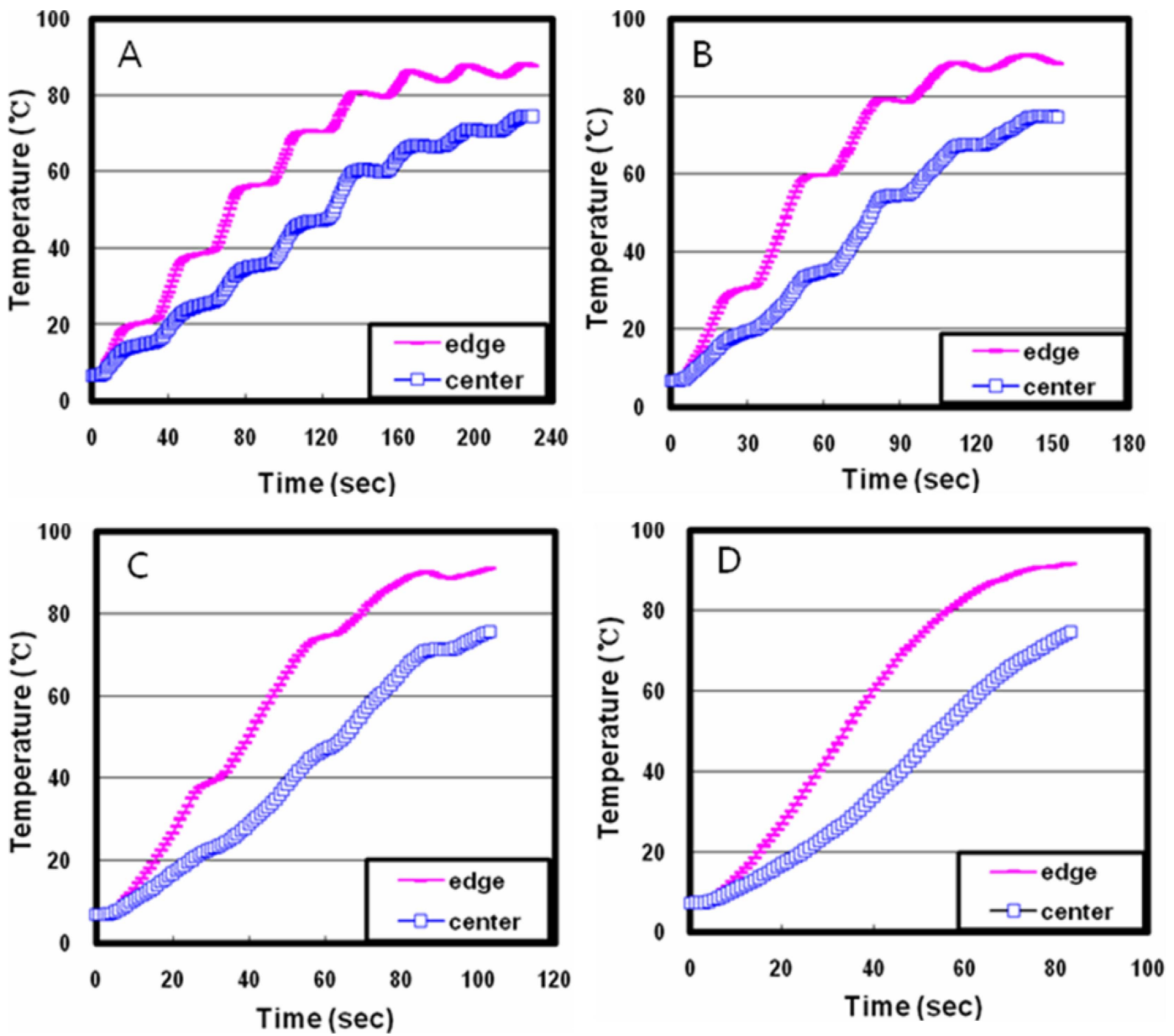

Fig. 2. Time-temperature profile at the center and edge position during microwave cooking of ground pork patties as affected by various power levels. A, $360 \mathrm{~W}$ power; $\mathrm{B}, 540 \mathrm{~W}$ power; $\mathrm{C}, 720 \mathrm{~W}$ power; $\mathrm{D}, 900 \mathrm{~W}$ power.
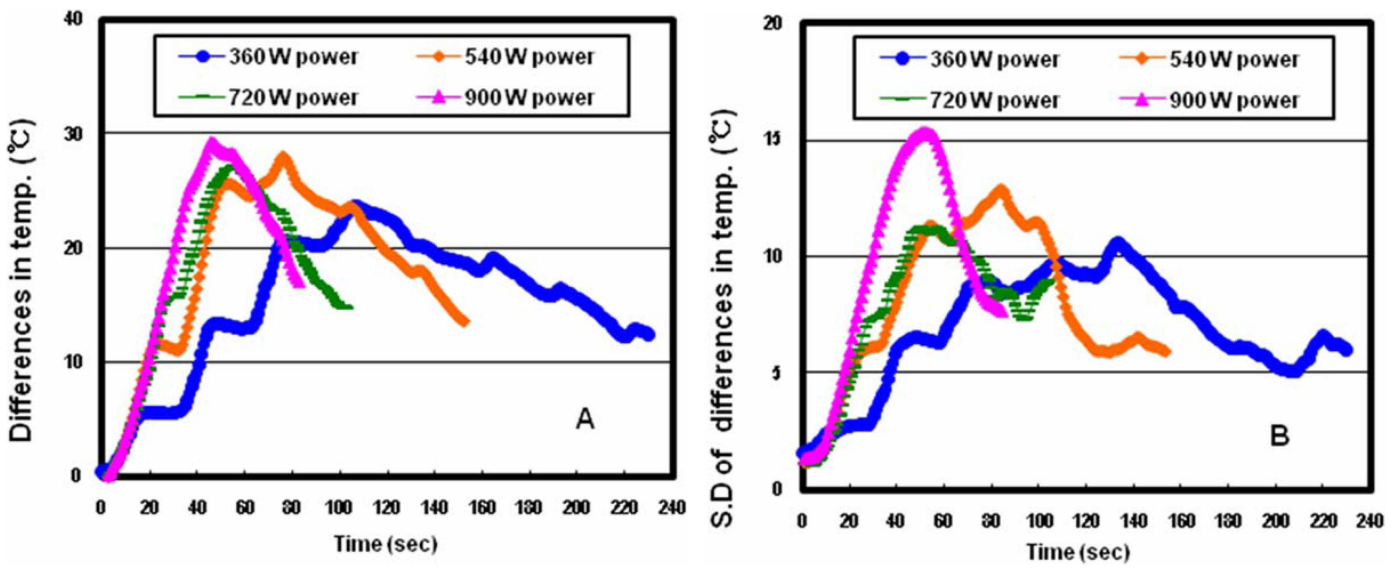

Fig. 3. Differences in temperature between at the edge and at the center position and their standard deviation during microwave cooking of ground pork patties as affected by various power levels. A: Differences in temperature between at the edge and at the center position, B: Standard deviation of differences in temperature between at the edge and at the center position.

position of ground pork patties cooked at various microwave power levels are shown in Fig. 4. Post-cooking temperature changes were influenced by fat content, patty size, cooking method, and location within the patty (Berry and Bigner-George, 2000, 2001; Lyon et al., 2000). Pat- ties cooked at $900 \mathrm{~W}$ showed the maximum temperature at the edges. However, these patties had a slightly faster cooling rate than those cooked at the other power levels. Unlike temperatures at the edges of the samples, changes of temperature at the center position were less in all pro- 

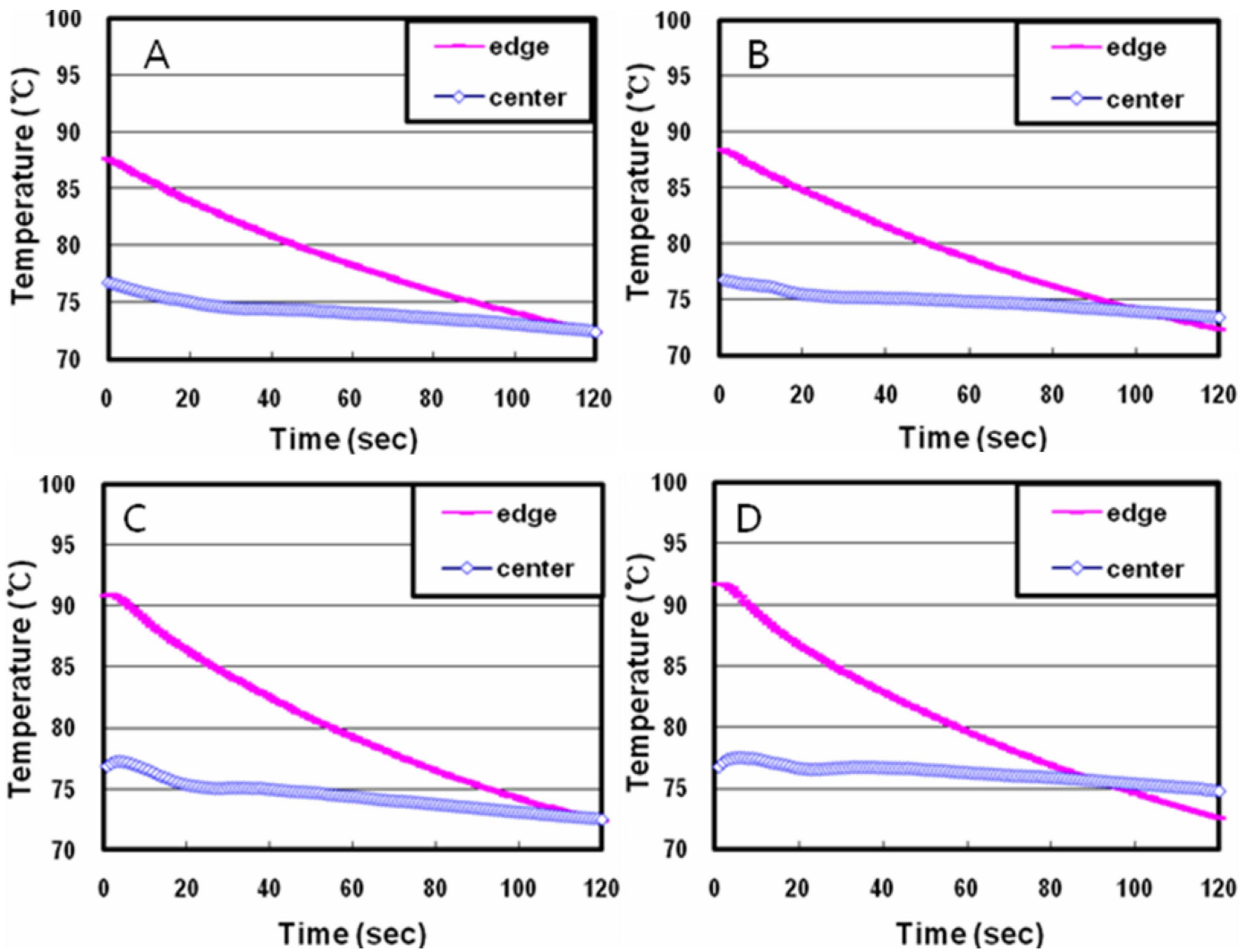

Fig. 4. Post-cooking temperature changes at the center and edge position in ground pork patties cooked by various microwave power levels. A: $360 \mathrm{~W}$ power, B: $540 \mathrm{~W}$ power, C: $720 \mathrm{~W}$ power, D: $900 \mathrm{~W}$ power.

cessed patties. Thus, by standing time for 2 min, the temperatures are equilibrated. It appears to be adequate for equilibration of temperature. Patties cooked at power levels greater than $540 \mathrm{~W}$ showed a post-cooking temperature rise in temperature of approximately $1^{\circ} \mathrm{C}$. Postcooking temperature rise is the increase in temperature after microwave cooking as measured at the coolest site in a product. This property varies with the size, shape, and internal temperature of the food (Knutson et al., 1987). Cho (1994) studied beef roasts heated in a microwave oven at three different power levels $(280,420$, and
$700 \mathrm{~W}$ ) and reported that post-cooking temperature rise increased with increasing power level. These trends were consistent with present study, although the values of postcooking temperature rise were considerably different from those of Cho (1994). These differences may be due to product dependent factors.

\section{pH values and compositional properties}

The $\mathrm{pH}$ values and compositional properties of ground pork patties as affected by various microwave power are presented in Table 1. The $\mathrm{pH}$ value in raw ground pork

Table 1. Compositional properties of raw and cooked ground pork patties at various microwave power levels

\begin{tabular}{clccccc}
\hline \hline \multirow{2}{*}{ Properties } & \multirow{2}{*}{ Position } & \multirow{2}{*}{ Raw } & \multicolumn{4}{c}{ Power level (W) } \\
\cline { 4 - 7 } & & & 360 & 540 & 720 & 900 \\
\hline $\mathrm{pH}$ & & $5.96 \pm 0.00$ & $6.10 \pm 0.00$ & $6.11 \pm 0.00$ & $6.10 \pm 0.00$ & $6.09 \pm 0.00$ \\
\hline \multirow{2}{*}{ Moisture content (\%) } & Edge & \multirow{2}{*}{$62.3 \pm 0.9$} & $52.2 \pm 0.6^{\mathrm{b}}$ & $52.7 \pm 0.4^{\mathrm{b}}$ & $53.9 \pm 0.4^{\mathrm{b}}$ & $53.7 \pm 0.9$ \\
& Center & & $55.3 \pm 0.5^{\mathrm{a}}$ & $54.8 \pm 0.5^{\mathrm{a}}$ & $55.6 \pm 0.5^{\mathrm{a}}$ & $54.6 \pm 0.6$ \\
\hline \multirow{2}{*}{ Fat content (\%) } & Edge & \multirow{2}{*}{$20.1 \pm 0.4$} & $22.4 \pm 0.3^{\mathrm{a}}$ & $21.5 \pm 0.6$ & $21.1 \pm 0.8$ & $22.1 \pm 0.8$ \\
& Center & & $20.8 \pm 0.4^{\mathrm{b}}$ & $20.9 \pm 0.7$ & $20.7 \pm 0.7$ & $20.5 \pm 0.7$ \\
\hline \multirow{2}{*}{ Protein content (\%) } & Edge & \multirow{2}{*}{$20.1 \pm 0.6$} & $24.5 \pm 0.8$ & $25.0 \pm 0.6$ & $24.1 \pm 0.7$ & $24.2 \pm 0.9$ \\
& Center & & $23.1 \pm 0.7$ & $23.6 \pm 0.7$ & $22.9 \pm 0.7$ & $24.1 \pm 0.9$ \\
\hline
\end{tabular}

All values are mean \pm SE of three replicates.

${ }^{\mathrm{a}, \mathrm{b}}$ Means sharing different letters in the same column are significantly different $(p<0.05)$. 
patties was 5.96. There were no significant differences $(p>0.05)$ among patties cooked at different power level. Fat content in raw ground pork patties were approximately close to designed levels. Fat, moisture, and protein content were not affected by microwave power levels. These results are consistent with those of Hines et al. (1980) and Cho (1994). Cho (1994) reported that the moisture, fat, and protein content in cooked roasts were not significantly difference among three different microwave power levels $(280,420$, and $700 \mathrm{~W})$. However, slight differences were observed between the edge and the center positions in the cooked patties. The center positions of patties cooked at $360 \mathrm{~W}$ to $720 \mathrm{~W}$ showed higher $(p<0.05)$ moisture content compared to the edge positions. This result probably may be caused by the edge overheating effect. Similar results were reported by Ni $e t$ al. (1999), who found that most of the moisture loss occurred from the edges due to higher temperature at these locations. Fat content of patties cooked at $360 \mathrm{~W}$ was higher $(p<0.05)$ at the edges than at the center position. However, no significant differences in fat content were observed between these positions in patties cooked at higher power levels. Protein content was not significantly different in among the different positions and patties cooked at different power levels.

\section{Cooking properties and shear force}

Patties cooked at $900 \mathrm{~W}$ showed the highest cooking rate and the lowest cooking time (Table 2). Nevertheless, total cooking loss and cooking drip loss of cooked ground pork patties were not affected $(p>0.05)$ by microwave power levels. Cho (1994) concluded that differences in cooking loss by cooking rate were not observed in the microwave cooked meat since the lack of surface browning resulted from different cooking pattern in the micro- wave cooking compared to the conventional cooking. However, patties cooked at $360 \mathrm{~W}$ had higher $(p<0.05)$ evaporation loss than did at $720 \mathrm{~W}$ and $900 \mathrm{~W}$, but showed no significant differences $(p>0.05)$ among patties cooked at $540 \mathrm{~W}$ to $900 \mathrm{~W}$. Similar results were reported by Hines et al. (1980), who found that microwave power level did not significantly affect drip loss for pork loin chops, although evaporation loss was higher for the chops cooked at the low microwave oven setting. Power level affected changes in diameter and thickness of the cooked patties. Patties cooked at $720 \mathrm{~W}$ and $900 \mathrm{~W}$ had larger changes in diameter $(p<0.05)$ than did at $540 \mathrm{~W}$ power. While, patties cooked at higher power levels had lower reduction in thickness than those at lower power levels. The patties cooked at $900 \mathrm{~W}$ had the lowest changes in thickness. Compared with higher microwave power levels $(720 \mathrm{~W}$ and $900 \mathrm{~W})$, ground pork patties cooked at lower microwave power levels ( $360 \mathrm{~W}$ and $540 \mathrm{~W}$ ) had higher shear force values. However, no differences were observed when comparing among lower power levels or higher power levels. Barbut and Mittal (1990) studied the effects of heating rate on the gelation, stability, and texture of meat batter. They found that slower heating rates generally resulted in higher rigidity values. Also, according to Foegeding et al. (1986) and Saliba et al. (1987), slow heating rates can allow more time for the protein to unfold and interact with each other, thus enabling a stronger gel matrix to be formed. These trends were also observed in the present study.

\section{Instrumental color evaluations}

In this study, a little effect of power levels on instrumental color was observed (Table 3). For the surface color, CIE L-values were not significantly affected by power level. No differences $(p>0.05)$ for CIE a-values were also

Table 2. Cooking properties and shear force values of ground pork patties cooked to internal temperature of $76.7^{\circ} \mathrm{C}$ at various microwave power levels

\begin{tabular}{|c|c|c|c|c|}
\hline \multirow{2}{*}{ Properties } & \multicolumn{4}{|c|}{ Power level (W) } \\
\hline & 360 & 540 & 720 & 900 \\
\hline Cooking time $(\mathrm{sec})$ & $229.5 \pm 4.3^{\mathrm{a}}$ & $151.6 \pm 3.4^{\mathrm{b}}$ & $106.9 \pm 2.6^{\mathrm{c}}$ & $87.4 \pm 1.8^{\mathrm{d}}$ \\
\hline Cooking rate $\left({ }^{\circ} \mathrm{C} / \mathrm{min}\right)$ & $18.3 \pm 0.3^{\mathrm{d}}$ & $29.2 \pm 0.4^{\mathrm{c}}$ & $40.1 \pm 0.6^{\mathrm{b}}$ & $48.4 \pm 0.6^{\mathrm{a}}$ \\
\hline Total cooking loss $(\%)$ & $25.2 \pm 0.2$ & $24.7 \pm 0.2$ & $24.3 \pm 0.3$ & $24.6 \pm 0.3$ \\
\hline Drip loss $(\%)$ & $16.7 \pm 0.3$ & $17.2 \pm 0.3$ & $17.3 \pm 0.3$ & $17.5 \pm 0.3$ \\
\hline Evaporation loss $(\%)$ & $8.4 \pm 0.4^{\mathrm{a}}$ & $7.5 \pm 0.5^{\mathrm{ab}}$ & $7.0 \pm 0.4^{\mathrm{b}}$ & $7.2 \pm 0.4^{\mathrm{b}}$ \\
\hline Reduction in patty diameter $(\%)$ & $25.6 \pm 0.3^{\mathrm{b}}$ & $25.7 \pm 0.3^{\mathrm{ab}}$ & $26.4 \pm 0.2^{\mathrm{a}}$ & $26.4 \pm 0.3^{\mathrm{a}}$ \\
\hline Reduction in patty thickness $(\%)$ & $18.2 \pm 0.2^{\mathrm{a}}$ & $18.0 \pm 0.2^{\mathrm{ab}}$ & $17.5 \pm 0.2^{\mathrm{bc}}$ & $17.3 \pm 0.2^{\mathrm{d}}$ \\
\hline Shear force $(\mathrm{kg})$ & $1.23 \pm 0.02^{\mathrm{a}}$ & $1.27 \pm 0.02^{\mathrm{a}}$ & $1.11 \pm 0.02^{\mathrm{b}}$ & $1.13 \pm 0.02^{b}$ \\
\hline
\end{tabular}

All values are mean \pm SE of three replicates.

${ }^{\mathrm{a}-\mathrm{d}}$ Means sharing different letters in the same row are significantly different $(p<0.05)$. 
Table 3. CIE $L$, a, b values of ground pork patties cooked by various microwave power levels

\begin{tabular}{ccccc}
\hline \hline \multirow{2}{*}{ Properties } & \multicolumn{4}{c}{ Power level (W) } \\
\cline { 2 - 5 } & 360 & 540 & 720 & 900 \\
\hline Surface & & & \\
L & $58.6 \pm 0.2$ & $59.3 \pm 0.4$ & $59.0 \pm 0.2$ & $59.1 \pm 0.2$ \\
a & $8.0 \pm 0.1$ & $7.9 \pm 0.2$ & $8.1 \pm 0.2$ & $7.7 \pm 0.2$ \\
b & $11.5 \pm 0.1^{\mathrm{b}}$ & $11.8 \pm 0.1^{\mathrm{ab}}$ & $12.0 \pm 0.2^{\mathrm{a}}$ & $11.9 \pm 0.2^{\mathrm{a}}$ \\
\hline Interior & & & \\
L & $67.8 \pm 0.2$ & $67.8 \pm 0.2$ & $68.0 \pm 0.1$ & $67.7 \pm 0.2$ \\
$\mathrm{a}$ & $4.8 \pm 0.1^{\mathrm{a}}$ & $4.8 \pm 0.1^{\mathrm{a}}$ & $4.5 \pm 0.1^{\mathrm{ab}}$ & $4.4 \pm 0.1^{\mathrm{b}}$ \\
$\mathrm{b}$ & $9.2 \pm 0.0$ & $9.3 \pm 0.0$ & $9.3 \pm 0.0$ & $9.3 \pm 0.0$ \\
\hline
\end{tabular}

All values are mean \pm SE of three replicates.

${ }^{a, b}$ Means sharing different letters in the same row are significantly different $(p<0.05)$.

observed among power levels, but CIE b-values were increased slightly with increasing power level. CIE Land CIE b-values for interior color were not affected by power level. However, the interior cooked color of pork patties became slightly less red in color (lower CIE a-values) as the microwave power levels increased. Regardless of power levels, the interior color of cooked patties had lighter (higher CIE L values) color and lower CIE a- and b-values compared to the surface color.

In ground pork patties, cooking rate increased with microwave power level and non-uniformity increased with time and power level. The influence by the edge overheating effect was observed at all power level, and its effect increased with power level. Nevertheless, microwave power level did not affect compositional properties, total cooking loss, and drip loss, even though little differences in changes in diameter and thickness of the cooked patties. Therefore, lower power levels would be useful to reduce the non-uniformity of heating and to improve the temperature distribution and product safety of meat patties.

\section{Acknowledgement}

This work was supported by the Korea Research Foundation Grant (KRF-2003-F00006). The authors also partially supported by the Brain Korea 21 (BK 21) Project from Ministry of Education and Human Resources Development, Republic of Korea.

\section{References}

1. Barbut, S. and Mittal, G. S. (1990) Effect of heating rate on meat batter stability, texture and gelation. J. Food Sci. 55,
334-337.

2. Berry, B. W. and Bigner-George, M. E. (2000) Factors affecting color properties of beef patties cooked on an outdoor gas grill. J. Muscle Foods 11, 213-226.

3. Berry, B. W. and Bigner-George, M. E. (2001) Postcooking temperature changes in beef patties. J. Food Prot. 64, 14051411.

4. Buffler, C. R. and Stanford, M. A. (1991) Effect of dielectric and thermal properties on the microwave heating of foods. Microw. World. 12, 15-23.

5. Chamchong, M. and Datta, A. K. (1999) Thawing of food in a microwave oven: I. Effect of power levels and power cycling. J. Microw. Power Electromagn. Energy 34, 9-21.

6. Cho, K. H. (1994) Effect of microwave cooking on roast heated to three different internal temperatures with three different microwave power levels. Korean J. Food Cookery Sci. 10, 394-404.

7. Decareau, R. V. (1985) Microwave in the food processing industry. Academic Press, Orlando, pp. 234.

8. Engelder, D. S. and Buffler, C. R. (1991) Measuring dielectric properties of food product at microwave frequencies. Microw. World 12, 2-11.

9. Fakhouri, M. O. and Ramaswamy, H. S. (1993) Temperature uniformity of microwave heated foods as influenced by product type and composition. Food Res. Int. 26, 89-95.

10. Foegeding, E. A., Allen, C. E., and Dayton, W. R. (1986) Effect of heating rate on thermally formed myosin, fibrinogen and albumin gels. J. Food Sci. 51, 104-108.

11. Hines, R. C., Ramsey, C. B., and Hoes, T. L. (1980) Effects of microwave cooking rate on palatability of pork loin chops. J. Anim. Sci. 50, 446-451.

12. Knutson, K. N., Marth, E. H., and Wagner, M. K. (1987) Microwave heating on the food. Lebensm.-Wiss. Technol. 22, 101-110.

13. Liu, M. N. and Berry, B. W. (1996) Variability in color, cooking times, and internal temperature of beef patties under controlled cooking conditions. J. Food Prot. 59, 969-975.

14. Lyon, B. G., Berry, B. W., Soderberg, D., and Clinch, N. (2000) Visual color and doneness indicators and the incidence of premature brown color in beef patties cooked to four end-point temperatures. J. Food Prot. 63, 1389-1398.

15. Mudgett, R. E. (1986) Microwave properties and heating characteristics of foods. Food Technol. 40, 84-93, 98.

16. Mudgett, R. E. (1988) Electromagnetic energy and food processing. J. Microw. Power Electromagn. Energy 23, 225230 .

17. Ni, H., Datta, A. K., and Parmeswar, R. (1999) Moisture loss as related to heating uniformity in microwave processing of solid foods. J. Food Process Eng. 22, 368-382.

18. Nykvist, W. E. and Decareau, R. V. (1976) Microwave meat roasting. J. Microw. Power 11, 3-24.

19. Ohlsson, T. (1999) Minimal processing of foods with electric heating methods. In: Processing foods: Quality optimization and process assessment. Oliveira, F. A. R. and Oliveira, J. C. (eds), CRC Press, FL, pp. 97-105.

20. Ohlsson, T. and Bengtsson, N. (2001) Microwave technol- 
ogy and foods. Adv. Food Nutri. Res. 43, 65-140.

21. Ohlsson, T., Henriques, M., and Bengtsson, N. (1974) Dielectric properties of model meat emulsion at 900 and $2800 \mathrm{Mhz}$ in relation to their composition. J. Food Sci. 39, 1153-1156.

22. Ohlsson, T. and Risman, P. O. (1978) Temperature distribution of microwave heating, spheres and cylinders. J. Microw. Power 13, 303-310.

23. Risman, P. O. (1992) Metal in the microwave oven. Microw. World 13, 28-33.

24. Saliba, D. A., Foegeding, E. A., and Hamann, D. D. (1987) Structural failure and nondestructive rheological analyses of frankfurter batter: effects of heating rates and sugars. J. Texture Stud. 18, 241-242.

25. SAS (1999) Statistical analysis system release 8.01. Cary,

\section{$\mathrm{NC}$, USA}

26. Schiffman, R. F. (1986) Food product development for microwave processing. Food Technol. 40, 94-98.

27. Zeng, X. and Faghri, A. (1994) Experimental and numerical study of microwave thawing heat transfer for food materials. J. Heat. Transfer. 116, 446-455.

28. Zhang, H. and Datta, A. K. (2000) Coupled electromagnetic and thermal modeling of microwave oven heating of foods. J. Microw. Power Electromagn. Energy 35, 71-85.

29. Zhang, L., Lyng, J. G., Brunton, N., Morgan, D., and McKenna, B. (2004) Dielectric and thermophysical properties of meat batter over a temperature range of $5-85^{\circ}$ C. Meat Sci. 68 , 173-184. 